\title{
PECAM1 Gene
}

National Cancer Institute

\section{Source}

National Cancer Institute. PECAM1 Gene. NCI Thesaurus. Code C20997.

This gene is involved in several cellular processes such as: thrombosis, hemostasis, immunity, and inflammatory responses. 